\title{
Interdisciplinary Study of Safety Perception of Urban Environment as a Factor Contributing to Development of Contemporary Urbanization Processes Typology
}

\author{
Ivan A. Drobyshev*, Svetlana N. Lykova, \\ Natalya D. Makushkina and Irina P. Vorontsova \\ Siberian Federal University \\ 79 Svobodny, Krasnoyarsk, 660041, Russia
}

Received 15.11.2017, received in revised form 04.12.2017, accepted 13.12.2017

The article depicts the results of a study focused on connection between factors of urban living environments and personal assessment of safety of these environments as places of potential or actual residence for young people aged 18 to 25 years. The collected data suggest that personal perception of safety for this category of respondents is not the main determinant for decision-making concerning a place of residence. The authors outline areas for further research in order to develop a model of urbanization processes for Siberian resource regions, observing Krasnoyarsk Krai as an example.

Keywords: urbanization processes, urban environment safety, young people.

The study was funded by Russian Foundation for Basic Research, project code 17-12-24013, Government of Krasnoyarsk Krai and Krasnoyarsk Regional Science and Technology Support foundation, project code KF-584. The general project title is "Methodological approaches to the typology of contemporary urbanization processes in resource regions of Siberia and modeling the impact of key urbanization factors level on innovational and technological, economic and socio-cultural development of a region (using Krasnoyarsky Kray as the model)".

DOI: 10.17516/1997-1370-0188.

Research area: economics.

\section{Introduction}

The processes of urbanization in resource regions of Siberia are defined by intra- and interregional migration of the population. Decision-making on changing a place of residence can be based on a relatively large set of factors sustainable for quantitative measurement, and the factors that suggest only subjective interpretation (Beall et al., 2010). Among the latter, the major ones are the factors of attractiveness of urban environment as a place of residence and practicing consumption, recreation and healthcare, education, etc.

The very image of a city is a universal and concept with a contradictory content; on the one hand, it is a "melting pot": a place where

(C) Siberian Federal University. All rights reserved

* Corresponding author E-mail address: idrobyshev@sfu-kras.ru 
innovations are created, where political, financial, social power concentrates, where changes are born. On the other hand, a city is a highly dangerous place (where the danger is "hidden"). It is usually a larger place (in comparison to the former place of residence) in terms of size and population; stereotypical anonymity of urban life, clear social segregation, inequality, stratification, high possibility and rate of conflicts (Beall et al., 2010) constitute duality of a city image - as an attractive and, at the same time, unsafe place for living.

This duality is emphasized by "social injustice" - as how urban environment is organized. Mirroring social relations, a city reflects segregation and inequality in quality of life by its structure - for example, through categories of a "city center" and "outskirts", which are usually remote from the center for considerable distances. (Ptichnikova, 2012). For last decades, these categories are undergoing a certain transformation due to formation of new channels of urban population mobility altogether with development of traditional channels. These channels contribute to preserve, deepen, or, vice versa, - to even the differences between a city center and remote areas: for example, by increasing the accessibility of central areas, where urban resources are concentrated, for inhabitants of peripheral districts. Another realistic scenario on changing localization of urban practices is development of city areas, peripheral in the past, by building places supplying goods and services, which are highly attractive to residents of central areas (e.g. shopping centers, hypermarkets, recreational zones, etc.), in old and/or former industrial areas.

Thus, modern urbanization processes change the image of a city, proposing a different way of consuming its resources for the inhabitants. Usage the "image" category implies the need to take into account not only the quantitative indicators on quality of urban environment, but also phenomena of subjective, or personal perception of most significant aspects of urban environment as a place of residence and the practicing urban way of living. Studying these phenomena already has a certain tradition (Ordonez and Berg, 2013; Salesses et al., 2013; Bogomaz et al., 2013; Bruner and Kruzhkova, 2015). At the same time, certain changes in a way one interacts with urban environment involve changing the factors influencing on how a choice of place of residence is made. In particular, the boundaries of stereotypically "dangerous" (usually peripheral) areas, which earlier would have been less preferred for living, are shifting or disappearing; city frontiers move farther from its center. At the same time, the safety factor continues to play a significant role for a city inhabitant (Valeraa and Guàrdia, 2014; Salimgareeva et al., 2015). This article explains the study of factors that determine personal perception on safety of residential urban spaces (courtyard space etc.). It is assumed that these factors play major role in choosing a place of residence, and indirectly affecting urbanization processes. The study was conducted among young people aged 18 to 25 years as the most mobile (as ready to change their place of residence) age group, directly involved in the development of new (newly built) urban areas.

\section{Materials and methods}

The empirical pilot study was aimed to identify the factors of residential urban spaces affecting personal assessment of safety of places of residence by young people. A research hypothesis in the basis of a questionnaire used to conduct the study suggested that the most significant ones were the following variables:

- Symbolic and real boundaries of a space;

- Natural and artificial obstacles and/or shelters (as also able to serve as shelters): their availability and type; 
- Landscaping and type of gardening;

- Traffic intensity in the residential spaces;

- Crowdedness of residential spaces;

- Signs of incivility: dilapidation, lack of maintenance, absence or brokenness of usual elements of courtyard spaces.

These variables were defined basing on analysis of literature describing different dimensions of the subjective (personal) experience of safety in a city: concepts of "protective space" by O. Newman (Newman, 1995), signs of incivility by A. Hunter (Hunter, 1978), the duality in perception of recreational areas (as an element of urban ecosystem and a source of danger) (Sreetheran and Konijnendijk van den Bosch, 2014; Valeraa and Guàrdia, 2014).

A dependent variable "Safety assessment of space" was operationalized with taking the materials of the focus group into account, which suggested a direct relationship between the perception of space as dangerous/safe and the time of day.

The convenience sample for the study consisted of 60 respondents - Krasnoyarsk residents aged 18 to 25 years (median age was 21 years). The main criteria for sampling were age and an area of residence, so that all administrative districts of the city were represented at the same time with the most of historically established urban districts: boundaries of these two district types usually do not coincide.

The data were checked for normal distribution by the Kolmogorov-Smirnov test. Next, a pairwise correlation analysis data was conducted using the Spearman's rank correlation coefficient.

\section{Results and discussion}

The obtained data indicate that the major factor that determines personal perception of space safety is the time of day. This finding is grounded, in particular, by the high correlation coefficient for safety assessment within two groups of time periods: firstly, $12 \mathrm{AM}-5 \mathrm{PM}$ and $5 \mathrm{PM}-$ 8 PM (0.73, p <.05), and secondly, 8 PM - 12 $\mathrm{PM}$ and $12 \mathrm{PM}-5$ AM $(\mathbf{0 . 7 4}, \mathrm{p}<0.05)$. The numbers suggest that city inhabitants perceive these two enlarged time intervals (from $12 \mathrm{AM}$ to $8 \mathrm{PM}$ and from $8 \mathrm{PM}$ to $5 \mathrm{AM}$ ) as relatively homogeneous; at least, the differences in the subjective safety assessment within these time intervals are significantly less than between them. For comparison, the correlation coefficient between the time intervals of 5 PM to 8 PM and $8 \mathrm{PM}$ to $12 \mathrm{PM}$ is $\mathbf{0 . 5 3}$ (also with a significance level of $\mathrm{p}<.05$ ).

Quite surprising finding was the lack of connection between the safety assessment of a space and its crowdedness (see Table 1). A number of literary sources (Jacobs and Lees, 2013; Newman, 1995; Reynald, 2015; Rollwagen, 2016) suggests that the presence of people in urban space is a factor contributing to perceiving it safer as being under mutual surveillance of inhabitants.

It is possible to explain these findings in two ways. The original theory of "protective space" focuses on public spaces - streets and squares that can be under "collective surveillance" of inhabitants over potential intruders. In addition, a number of authors (primarily from the field of criminology and victimology) pointed to certain methodological flaws of Newman's original sociological concept that limit its applicability: for example, a review of critical views on the Newman concept in (Eck and Weisburd, 2015)). Overcoming this contradiction is possible through obtaining additional data on the relationship between "protective" characteristics of space and the personal assessment of its safety.

Certain threats and hazards of courtyard spaces have different significance for respondents, depending on the time of day. Strong 
Table 1. Correlation between the crowdedness of residential space and space safety

\begin{tabular}{|c|c|c|c|c|c|c|}
\hline \multirow{2}{*}{$\begin{array}{c}\text { Crowdedness of } \\
\text { residential space }\end{array}$} & \multicolumn{7}{|c|}{ Assessment of space safety (by time) } \\
\cline { 2 - 7 } & $\begin{array}{c}5 \mathrm{AM}- \\
10 \mathrm{AM}\end{array}$ & $\begin{array}{c}10 \mathrm{AM}- \\
12 \mathrm{AM}\end{array}$ & $\begin{array}{c}12 \mathrm{AM}- \\
5 \mathrm{PM}\end{array}$ & $\begin{array}{c}5 \mathrm{PM}- \\
8 \mathrm{PM}\end{array}$ & $\begin{array}{c}8 \mathrm{PM}- \\
12 \mathrm{PM}\end{array}$ & $\begin{array}{c}12 \mathrm{PM}- \\
5 \mathrm{AM}\end{array}$ \\
\hline $5 \mathrm{AM}-10 \mathrm{AM}$ & 0,017 & 0,015 & $-0,088$ & $-0,068$ & $-0,258$ & $-0,24$ \\
\hline $10 \mathrm{AM}-12 \mathrm{AM}$ & $-0,17$ & 0,132 & $-0,274$ & $-0,086$ & 0,05 & 0,005 \\
\hline $12 \mathrm{AM}-5 \mathrm{PM}$ & $-0,016$ & $\mathbf{- 0 , 2 6 6 *}$ & $-0,032$ & 0,13 & 0,12 & 0,175 \\
\hline $5 \mathrm{PM}-8 \mathrm{PM}$ & $-0,195$ & $-0,114$ & 0,214 & 0,065 & $-0,213$ & $\mathbf{- 0 , 2 7 6 ^ { * }}$ \\
\hline $8 \mathrm{PM}-12 \mathrm{PM}$ & $\mathbf{- 0 , 2 7 8 *}$ & $-0,011$ & $-0,056$ & $-0,003$ & $-0,285^{*}$ & $-0,367^{*}$ \\
\hline $12 \mathrm{PM}-5 \mathrm{AM}$ & $\mathbf{- 0 , 3 3 8 *}$ & $-0,018$ & $-0,098$ & $-0,094$ & $-\mathbf{0 , 3 3 5}$ & $-0,315^{*}$ \\
\hline
\end{tabular}

* - Marked correlations are significant at $\mathrm{p}<.05000$

Table 2. Correlation between safety perception factors and assessment of environment safety

\begin{tabular}{|c|c|c|c|c|c|c|}
\hline \multirow{2}{*}{$\begin{array}{c}\text { Safety perception } \\
\text { factors }\end{array}$} & \multicolumn{7}{|c|}{ Assessment of environment safety (by time) } \\
\cline { 2 - 7 } & $\begin{array}{c}5 \mathrm{AM}- \\
10 \mathrm{AM}\end{array}$ & $\begin{array}{c}10 \mathrm{AM}- \\
12 \mathrm{AM}\end{array}$ & $\begin{array}{c}12 \mathrm{AM}- \\
5 \mathrm{PM}\end{array}$ & $\begin{array}{c}5 \mathrm{PM}- \\
8 \mathrm{PM}\end{array}$ & $\begin{array}{c}8 \mathrm{PM}- \\
12 \mathrm{PM}\end{array}$ & $\begin{array}{c}12 \mathrm{PM}- \\
5 \mathrm{AM}\end{array}$ \\
\hline $\begin{array}{c}\text { Possible injury and/or } \\
\text { trauma sources }\end{array}$ & $\mathbf{- 0 , 2 3 8 *}$ & $-0,493$ & $-0,217$ & $-0,585$ & $\mathbf{- 0 , 6 7 9 *}$ & $-0,805$ \\
\hline $\begin{array}{c}\text { Signs of incivility in } \\
\text { neighborhood }\end{array}$ & $-0,053$ & 0,084 & 0,231 & $\mathbf{0 , 3 5 4 *}$ & 0,247 & $\mathbf{- 0 , 6 1 9 *}$ \\
\hline $\begin{array}{c}\text { Signs of incivility in } \\
\text { apartment building }\end{array}$ & $-0,281$ & $-0,128$ & 0,121 & $-0,327$ & $-0,577$ & $-0,743^{*}$ \\
\hline
\end{tabular}

* - Marked correlations are significant at $\mathrm{p}<.05000$

Table 3. Correlation between safety perception factors and assessment of environment safety (part 2)

\begin{tabular}{|c|c|c|c|c|c|c|}
\hline \multirow{2}{*}{ Safety perception factors } & \multicolumn{7}{|c|}{ Assessment of environment safety (by time) } \\
\cline { 2 - 7 } & $\begin{array}{c}5 \mathrm{AM}- \\
10 \mathrm{AM}\end{array}$ & $\begin{array}{c}10 \mathrm{AM}- \\
12 \mathrm{AM}\end{array}$ & $\begin{array}{c}12 \mathrm{AM}- \\
5 \mathrm{PM}\end{array}$ & $\begin{array}{c}5 \mathrm{PM}- \\
8 \mathrm{PM}\end{array}$ & $\begin{array}{c}8 \mathrm{PM}- \\
12 \mathrm{PM}\end{array}$ & $\begin{array}{c}12 \mathrm{PM}- \\
5 \mathrm{AM}\end{array}$ \\
\hline $\begin{array}{c}\text { Natural and symbolic } \\
\text { boundaries and security } \\
\text { systems }\end{array}$ & 0,197 & $-0,099$ & $-0,077$ & $-0,076$ & 0,016 & 0,12 \\
\hline $\begin{array}{c}\text { Plants and green areas } \\
\text { Cars in residential spaces }\end{array}$ & $-0,13$ & $-0,179$ & $-0,201$ & $-0,117$ & 0,003 & 0,01 \\
\hline $\begin{array}{c}\text { Construction sites and } \\
\text { activities }\end{array}$ & 0,271 & 0,494 & 0,377 & 0,237 & 0,175 & 0,224 \\
\hline Stray animals & $-0,036$ & $-0,11$ & $-0,231$ & $-0,159$ & $\mathbf{- 0 , 3 2 5 *}$ & $-0,26$ \\
\hline
\end{tabular}

* - Marked correlations are significant at $p<.05000$

connections are found between subjective safety assessment and the possibility of traumatization, as well as signs of incivility in the residential areas (outside living apartment buildings) and inside outside the living apartment buildings (see Table 2).
In general, the interpretation of these data does not contradict common sense: the less visible the potential sources of traumatization and the signs of the incivility are, the safer it is perceived by the city inhabitants. However, it is interesting that this effect is clearly seen only at night. 
It is also interesting, that there is no direct connection between safety assessment of the of the city space as "high" and the following factors: the intensity of the car traffic inside the courtyard spaces (which may indicate the car's nonperception of a car as a potential threat to health and/or life), the presence of natural or symbolic borders (fences, gates, surveillance systems), greenery, construction sites, stray animals (see Table 3).

\section{Conclusion}

During the study, the data on significance of different factors of residential (courtyard) urban spaces for personal assessment of safety by youth in age from 18 to 25 years old were collected. The data suggest that the factors that can be described as "wellness" (or "well-being") of residential urban spaces have a relatively limited significance for young people. This leads us to assumption that the choice of a place of residence being made by young people is determined by factors of different nature. The safety of a place of residence, despite its apparent importance, is not a major defining characteristic of the quality of life in the urban space for young people of studied age category. This finding should be taken into account when modeling the urbanization processes of the region. The possible continuation of research in this area may be related to the study of urban mobility channels, the availability of places of implementation of urban practices, the localization of these practices in the urban areas of the region.

\section{References}

Beall, J., Guha-Khasnobis, B., Kanbur, R. (2010). Beyond the tipping point: a multidisciplinary perspective on urbanization and development: Urbanization and Development: Multidisciplinary Perspectives. New York, Oxford University Press. 3-27. Availible at:: http://ageconsearch.tind. io/record/51179/files/WP\%20Kanbur\%202009-18\%20Beyond\%20the\%20Tipping\%20Point.pdf (accessed on October 6th, 2017)

Bogomaz, S.A., Litvina, S.A., Chetoshnikova, E.V. (2013). Sub"ektivnaya ocenka gorodskoj sredy’ vuzovskoj molodezh 'yu Tomska i Barnaula [Personal assessment of urban environment by college students of Tomsk and Barnaul]. In Siberian Journal of Psychology, 49, 102-112.

Bruner, T.I., Kruzhkova, O.V. (2015). Strategiya vzaimodey'stviya molodezhi megapolisa s gorodskoy' sredoy' [Strategy of interaction between young people and urban environment]. In Pedagogical Education in Russia, 11, 76-82.

Eck, J.E., Weisburd, D.L. (2015). Crime Places in Crime Theory. Crime and Place: Crime Prevention Studies, 4, 1-33. Available at SSRN: https://ssrn.com/abstract=2629856 (accessed on October 2th, 2017)

Hunter A. (1978). Symbols of Incivility - Social Disorder and Fear of Crime in Urban Neighborhoods. Evanston, Northwestern University. NCJ 082421.

Jacobs, J.M., Lees, L. (2013). Defensible Space on the Move: Revisiting the Urban Geography of Alice Coleman. In Int J Urban Reg Res, 37: 1559-1583. doi:10.1111/1468-2427.12047

Newman, O. (1995). Defensible Space: A New Physical Planning Tool for Urban Revitalization. In Journal of the American Planning Association, 61(2), 149-155, doi:10.1080/01944369508975629

Ordonez, V., Berg, T.L. (2014). Learning High-Level Judgments of Urban Perception. In Fleet D., Pajdla T., Schiele B., Tuytelaars T. (eds) Computer Vision-ECCV 2014. ECCV 2014. Lecture Notes in Computer Science, vol. 8694, Springer 
Ptichnikova, G.A. (2012). “Nespravedlivy’j gorod”: gorodskoe prostarnstvo kak otrazhenie obshhestvenny’x otnoshenij [“Unfair city”: urban space as reflection of social relations]. In Sociology of City, 3, 47-54

Reynald, D.M. (2015). Environmental Design and Crime Events. In Journal of Contemporary Criminal Justice, 31(1), 71-89, doi: 10.1177/1043986214552618

Rollwagen, H. (2016). The Relationship Between Dwelling Type and Fear of Crime. Environment and Behavior, 48(2), 365-387, doi: 10.1177/0013916514540459

Salesses, P., Schechtner, K., Hidalgo, C.A. (2013). The Collaborative Image of The City: Mapping the Inequality of Urban Perception. In PLoS ONE 8(7), e68400, pmid:23894301

Salimgareeva, M.S., Vy'tovtov, A.V., Shumilin, V.V. (2015). Vliyanie bezopasnosti v osnovny'x zhily'x tipologiyax na udovletvoryonnost' zhizn'yu [Impact of safety on satisfaction over one's quality of life in basic residential typologies]. In Problemy obespecheniya bezopasnosti pri likvidacii posledstvij chrezvy'chajny'x situacij, 1, 33-38

Sreetheran, M., Konijnendijk van den Bosch, C.C. (2014). A Socio-Ecological Exploration of Fear of Crime in Urban Green Spaces - A Systematic Review. In Urban Forestry \& Urban Greening, 13(1), 1-18, doi: 10.1016/j.ufug.2013.11.006

Valeraa, S., Guàrdia, J. (2014). Perceived insecurity and fear of crime in a city with low-crime rates. In Journal of Environmental Psychology, 38, 195-205

Xiaojiang, L., Chuanrong, Zh., Weidong, L. (2015). Does the Visibility of Greenery Increase Perceived Safety in Urban Areas? Evidence from the Place Pulse 1.0 Dataset. In ISPRS Int. J. Geo-Inf., 4(3), 1166-1183; doi:10.3390/ijgi4031166

\title{
Междисциплинарное исследование \\ восприятия безопасности городской среды \\ как фактора типологизации процессов \\ урбанизации
}

\author{
И.А. Дробышев, С.Н. Лыкова, \\ Н.Д. Макушкина, И.П. Воронцова \\ Сибирский федеральный университет \\ Россия, 660041, Красноярск, пр. Свободный, 79
}

В статье описываются результаты исследования связи факторов благоустроенности жилых городских пространств и субъективной оиенки безопасности этих пространств как места потенциального или реального проживания для молодежи в возрасте от 18 до 25 лет. Данные исследования позволяют предположить, что субъективное восприятие безопасности не носит решающего характера в определении места жительства для указанной категории респондентов. Намечаются дальнейшие перспективные направления исследований для моделирования прочессов урбанизации ресурсных регионов Сибири на примере Красноярского края.

Ключевые слова: процессы урбанизаиии, безопасность городской среды, молодежь. 
Исследование поддержано Российским фондом фундаментальных исследований, проект № 17-12-24013, и Красноярским краевым фондом поддержки научной и научно-технической деятельности, проект № КФ-584. Общее название исследовательского проекта: «Методологические подходы к типологизации современных процессов урбанизации территорий ресурсных регионов Сибири и моделирование влияния уровня ключевых факторов урбанизачии на инноваџионно-технологическое, экономическое и сочиокультурное развитие региона (на примере Красноярского края)».

Научная специальность: 08.00.00 - экономические науки. 